\title{
GAMBARAN KEJADIAN HIPEREMESIS GRAVIDARUM DI BIDAN PRAKTEK MANDIRI ST. NILAWATI S.ST
}

\author{
Feby Purnamasari \\ Prodi Kebidanan, Sekolah Tinggi Ilmu Kesehatan Salewangang Maros \\ Email : febypurnamasari934@gmail.com
}

\begin{abstract}
Abstrak
Penelitian ini bertujuan untuk mengetahui gambaran Kejadian Hiperemesis Gravidarum Berdasarkan Umur Ibu, Umur kehamilan Ibu, dan Gravida ibu di Bidan Praktek Mandiri ST. Nilawati S.ST. Penelitian ini adalah jenis penelitian survey dengan metode pendekatan deskriptif yang bermaksud memberikan gambaran tentang kejadian Hiperemesis Gravidarum pada ibu hamil. Pengambilan sampel dengan cara Non Random Sampel (Purposive Sampling) Adalah metode dengan menggunakan kriteria yang telah dipilih oleh peneliti dalam memilih. Kriteria yang ditentukan oleh peneliti yaitu ibu hamil dengan muntah yang terus menerus, nafsu makan yang berkurang, berat badan menurun. Data yang dikumpulkan berupa data sekunder yang diperoleh dengan mempelajari catatan atau laporan dan buku register di Bidan Praktek Mandiri ST.Nilawati S.ST. Data dianalisis dengan Analisis data yang dilakukan adalah analisis deskriptif dengan rumus dan Pengolahan data dilakukan secara manual dalam bentuk tabel frekuensi dan presentasi dengan penjelasan tabel dalam naskah atau narasi. Hasil penelitian menunjukkan bahwa adi kesimpulannya terdapat $51(68 \%)$ kasus dengan kejadian hiperemesis gravidarum, yang berisiko tinggi berdasarkan umur ibu yaitu umur $<20$ - >35 tahun, lebih banyak terjadi pada gravida 1 dan $>3$, dan terjadi pada umur kehamilan $<16$ minggu.
\end{abstract}

Kata kunci : Hiperemesis Gravidarum, Umur Ibu, Umur kehamilan Ibu, dan Gravida ibu

\begin{abstract}
Description of hyperemesis gravidarum in midwife practice independently ST. NILAWATI S.ST. This study aims to determine the description of the occurrence of Gravidarum Hyperemesis based on maternal age, maternal age of the pregnancy, and Gravida in midwife practice independently ST. Nilawati S.ST. Hyperemesis Gravidarum in pregnant women. Sampling by non-random sample (purposive sampling) is a method using the criteria that have been selected by the researcher in selecting. The criteria determined by the researchers were pregnant women with continuous vomiting, decreased appetite, decreased body weight. The data collected is in the form of secondary data obtained by studying records or reports and register books at the Midwife Mandiri Practice ST. Nilawati S.ST. The data were analyzed using data analysis. The data were analyzed using descriptive analysis with formulas and data processing was done manually in the form of frequency tables and presentations with table explanations in the script or narrative. The results showed that there were 51 (68\%) cases with hyperemesis gravidarum, which had a high risk based on maternal age, namely age $<20->35$ years, more common in gravida 1 and $>3$, and occurred at gestational age $<16$ Sunday. The results showed that there were 51 (68\%) cases with hyperemesis gravidarum, which had a high risk based on maternal age, namely age <20 -> 35 years, more common in gravida 1 and $>3$, and occurred at gestational age $<16$ Sunday.
\end{abstract}

Keywords: Hyperemesis Gravidarum, Mother age, Mother Gestational age, Mother Gravida 


\section{Pendahuluan}

Kehamilan dan kelahiran merupakan kejadian normal dalam kehidupan, walaupun hal tersebut adalah suatu yang normal tetapi potensi terjadinya patologi pada wanita tetap ada, semua individu mempunyai resiko/potensial terjadinya patologis bagi ibu maupun janin. (Handayani, 2018; Larasati, 2018).

Mual dan muntah (morning sickness, Emesis Gravidarum) adalah mual dan muntah selama kehamilan yang terjadi antara empat dan delapan minggu kehamilan dan terus berlanjut hingga 14-16 minggu kehamilan dan gejala biasanya akan membaik. Mual dan muntah selama kehamilan dapat berupa gejala yang ringan hingga berat.Mual dan muntah adalah keluhan utama pada $70-80 \%$ kehamilan yang dapat mengganggu aktivitas sehari-hari dan dapat menyebabkan tubuh ibu menjadi lemah, muka pucat, dan frekuensi buang air kecil menurun. (Saifuddin, 2011; Atika, 2016; Andria, 2017; Ali, 2018; Rofi'ah, 2019; Sumae, 2014)

Kejadian hiperemesis gravidarum berlangsung sejak usia kehamilan 9-10 minggu. Kejadian ini makin berkurang dan selanjutnya diharapkan berakhir pada usia kehamilan 12-14 minggu. sebagian kecil berlanjut sampai usia kehamilan 20-24 minggu. (Magfirah Anita, 2013)
Mual dan muntah terjadi pada wanita hamil trimester I dan trimester II dapat berlangsung sampai 4 bulan yang dapat mengganggu keadaan umum ibu hamil seharihari, kondisi ini disebut hiperemesis gravidarum. (Marlina Rahma, 2016)

Hiperemesis gravidarum menyebabkan tidak seimbangnya cairan, elektrolit, asambasa, defisiensi nutrisi, dan kehilangan berat badan yang cukup berat. Pada hiperemesis gravidarum dapat terjadi dehidrasi, asidosis akibat kelaparan, alkalosis akibat hilangnya asam hidroklorida pada saat muntah, hipokalemia dan ketonuria, sehingga mengharuskan pasien masuk dan dirawat di rumah sakit. (Wirakusumah, 2011; Cunningham, 2006)

World Health Organization (WHO) memperkirakan angka kematian ibu sebesar 500.000 jiwa dan angka kematian bayi sebesar 10 juta jiwa setiap tahun.Kejadian kematian ibu dan bayi sebagian besar terdapat di negara berkembang yaitu sebesar 98\%-99\% lebih tinggi dibandingkan negara maju. (Oktavia, 2016).

Tingginya angka kematian ibu sangat bervariasi, dari beberapa sumber yang salah satunya menurut WHO pada tahun 2014 memperkirakan sebanyak 536.000 perempuan meninggal dunia akibat masalah kehamilan, persalinan dan nifas. Kejadian ini dapat 
berakibat $99 \%$ kematian ibu terjadi di Negaranegara berkembang. (Handayani, 2018).

Hiperemesis Gravidarum jarang menyebabkan kematian, tetapi angka kejadiannya masih cukup tinggi. Hampir 25\% pasien Hiperemesis Gravidarum dirawat inap lebih sekali.Terkadang, kondisi Hiperemesis Gravidarum terus-menerus dan sulit sembuh membuat pasien depresi. Pada kasus-kasus ekstrim, ibu-ibu hamil bahkan dapat merasa ingin melakukan terminasi kehamilan (Kevin, dkk, 2011)

Data yang diperoleh dari RSKDIA Siti Fatimah Makassar pada tahun 2010 jumlah ibu hamil sebanyak 1008 orang dan yang terdiagnosa hiperemesis sebanyak 21 orang, pada tahun 2011 jumlah ibu hamil sebanyak 1030 orang dan terdiagnosa hiperemesis sebanyak 60 orang, dan pada 1 bulan terakhir pada bulan Mei 2012 jumlah ibu hamil sebanyak 50 orang dan terdiagnosa hiperemesis sebanyak 30 orang. (Nurnaningsih, 2012)

Berdasarkan data yang diperoleh dari buku register kunjungan ibu hamil di Bidan Praktik Mandiri ST.Nilawati S.ST tahun 2017 sebanyak 17 orang yang hiperemesis gravidarum, kemudian di tahun 2018 sebanyak 22 ibu hamil yang hiperemesis, dan tahun 2019 terdapat $45 \mathrm{ibu}$ hamil yang hiperemesis gravidarum, ibu hamil yang memeriksakan kehamilannya pada periode Januari-Desember 2019. (Buku Register ST.Nilawati S.ST)

Berdasarkan pada tinggi nya angka kesakitan dan kasus hiperemesis dan melihat dari jumlah ibu hamil yang hiperemesis selama tahun 2017-2019 terjadi kenaikan di di Bidan Praktik Mandiri ST.Nilawati S.ST, maka penulis tertarik untuk melakukan penelitian tentang "Gambaran Kejadian Hiperemesis Gravidarum di Bidan Praktek Mandiri ST.Nilawati S.ST"

\section{Metode}

Penelitian ini adalah jenis penelitian survey dengan metode pendekatan deskriptif yang bermaksud memberikan gambaran tentang kejadian Hiperemesis Gravidarum pada ibu hamil. Pengambilan sampel dengan cara Non Random Sampel (Purposive Sampling) Adalah metode dengan menggunakan kriteria yang telah dipilih oleh peneliti dalam memilih. Kriteria yang ditentukan oleh peneliti yaitu ibu hamil dengan muntah yang terus menerus, nafsu makan yang berkurang, berat badan menurun. Data yang dikumpulkan berupa data sekunder yang diperoleh dengan mempelajari catatan atau laporan dan buku register di Bidan Praktek Mandiri ST. Nilawati S.ST

Populasi dalam penelitian ini adalah semua ibu hamil yang memeriksakan kehamilannya di Bidan Praktek Mandiri 
ST.Nilawati S.ST sebanyak 75 orang. Adapun sampel dalam penelitian ini adalah semua ibu hamil dengan kejadian Hiperemesis Gravidarum yang tercatat pada buku register Bidan Praktek Mandiri ST. Nilawati S.ST sebanyak 51 orang. Pengambilan sampel dengan cara Non Random Sampel (Purposive Sampling) Adalah metode dengan menggunakan kriteria yang telah dipilih oleh peneliti dalam memilih. Kriteria yang ditentukan oleh peneliti yaitu ibu hamil dengan muntah yang terus menerus, nafsu makan yang berkurang, berat badan menurun.

Data dianalisis dengan Analisis data yang dilakukan adalah analisis deskriptif dengan rumus $=\frac{f}{n} \times 100 \%$. Pengolahan data dilakukan secara manual dalam bentuk tabel frekuensi dan presentasi dengan penjelasan tabel dalam naskah atau narasi.

\section{Hasil}

Kejadian Hiperemesis Gravidarum merupakan indikator yang dapat menggambarkan status kesehatan ibu dalam upaya pembinaan kesehatan keluarga, pembinaan kesehatan ibu perlu mendapat perhatian yang utama.Hal ini sangat penting karena ibu yang sehat lebih mudah mendorong terciptanya keluarga yang sehat.

Peneliti mengambil lokasi karena ingin meneliti bagaimana angka kejadian
Hiperemesis Gravidarum Di Bidan Praktek Mandiri ST. Nilawati S.ST. Sasaran obyek pada penelitian ini adalah para ibu hamil. Penelitian tentang Gambaran Kejadian Hiperemesis Gravidarum Di Bidan Praktek Mandiri ST. Nilawati S.ST didapatkan 75 kunjungan ibu hamil, dimana kehamilan dengan kejadian Hiperemesis Gravidarum sebanyak 51 kasus pada ibu hamil primigravida dan multigravida.

\section{Hasil Kejadian Hiperemesis Gravidarum pada Ibu Hamil}

Tabel 1. Hasil Kejadian Hiperemesis Gravidarum pada Ibu Hamil

\begin{tabular}{llcc}
\hline No & $\begin{array}{l}\text { Hiperemesis } \\
\text { Gravidarum }\end{array}$ & Frekuensi & $\mathbf{( \% )}$ \\
\hline $\mathbf{1}$ & $\begin{array}{l}\text { Ibu hamil yang } \\
\text { hiperemesis }\end{array}$ & 51 & $68 \%$ \\
\hline $\mathbf{2}$ & $\begin{array}{l}\text { Ibu yang tidak } \\
\text { mengalami } \\
\text { hiperemesis }\end{array}$ & 24 & $32 \%$ \\
\hline & Jumlah & $\mathbf{7 5}$ & $\mathbf{1 0 0 \%}$ \\
\hline
\end{tabular}

Sumber data sekunder : Buku Register Bidan Praktek Mandir ST. Nilawati S.ST

\section{Hasil Kejadian Hiperemesis Gravidarum Berdasarkan Umur Ibu}

Tabel 2. Gambaran Kejadian Hiperemesis Gravidarum Berdasarkan Umur Ibu

\begin{tabular}{clcc}
\hline No & Umur Ibu & Frekuensi & $(\boldsymbol{\%})$ \\
\hline $\mathbf{1}$ & $\begin{array}{l}\text { Risiko } \\
\text { Tinggi } \\
(<20->35)\end{array}$ & 8 & $10,7 \%$ \\
\hline $\mathbf{2}$ & $\begin{array}{l}\text { Risiko } \\
\text { Rendah } \\
(20-35)\end{array}$ & 67 & $89,3 \%$ \\
\hline & Jumlah & $\mathbf{7 5}$ & $\mathbf{1 0 0 \%}$ \\
\hline
\end{tabular}


Sumber data sekunder : Buku Register Bidan Praktek Mandiri ST. Nilawati S.ST

\section{Hasil Kejadian Hiperemesis Gravidarum Berdasarkan Umur Kehamilan Ibu}

Tabel 3. Gambaran Kejadian Hiperemesis Gravidarum Berdasarkan Umur Kehamilan Ibu

\begin{tabular}{llcc}
\hline No & Umur Ibu & Frekuensi & $\mathbf{( \% )}$ \\
\hline $\mathbf{1}$ & $\begin{array}{l}\text { Risiko Tinggi } \\
(<16 \text { Minggu) }\end{array}$ & 6 & $8 \%$ \\
\hline & $\begin{array}{l}\text { Risiko } \\
\mathbf{2}\end{array}$ & $\begin{array}{l}\text { Rendah } \\
(\geq 16\end{array}$ \\
& Minggu) & 69 & $92 \%$ \\
\hline & Jumlah & $\mathbf{7 5}$ & $\mathbf{1 0 0 \%}$ \\
\hline
\end{tabular}

Sumber data sekunder : Buku Register Bidan Praktek Mandiri ST. Nilawati S.ST

\section{Hasil Kejadian Hiperemesis Gravidarum Berdasarkan Gravida Ibu}

Table 4 Gambaran Kejadian Hiperemesis Gravidarum Berdasarkan Gravida Ibu

\begin{tabular}{llcl}
\hline No & Umur Ibu & Frekuensi & $(\mathbf{\%})$ \\
\hline $\mathbf{1}$ & $\begin{array}{l}\text { Risiko Tinggi } \\
(1->3)\end{array}$ & 40 & $53 \%$ \\
\hline $\mathbf{2}$ & $\begin{array}{l}\text { Risiko } \\
\text { Rendah } \\
(2-3)\end{array}$ & 35 & $46,7 \%$ \\
\hline & Jumlah & $\mathbf{7 5}$ & $\mathbf{1 0 0 \%}$ \\
\hline
\end{tabular}

Sumber data sekunder : Buku Register Bidan Praktek Mandiri ST. Nilawati S.ST.

\section{Pembahasan}

Penelitian tentang Gambaran Kejadian Hiperemesis Gravidarum Di Bidan Praktek Mandiri ST. Nilawati S.ST didapatkan 75 kunjungan ibu hamil, dimana kehamilan dengan kejadian Hiperemesis Gravidarum sebanyak 51 kasus

\section{Hasil Kejadian Hiperemesis Gravidarum pada Ibu Hamil}

Pada penelitian menunjukkan bahwa dari 75 ibu hamil di Bidan Praktek Mandiri ST. Nilawati S.ST, terdapat 51 (68\%) ibu hamil yang mengalami Hiperemesis Gravidarum dan terdapat $24(32 \%)$ ibu hamil yang tidak mengalami Hiperemesis Gravidarum.

\section{Hasil Kejadian Hiperemesis Gravidarum Berdasarkan Umur Ibu}

Berdasarkan tabel 2 terlihat bahwa dari 75 ibu hamil di Bidan Praktek Mandiri ST.Nilawati S.ST sebanyak $8(10,7 \%)$ ibu hamil yang mengalami Hiperemesis Gravidarum pada umur $<20$ dan $>35$ tahun. Dan terdapat $67(89,3 \%)$ ibu hamil yang mengalami Hiperemesis Gravidarum pada umur 20- 35 tahun.

Hasil penelitian ini sesuai dengan teori Larasati (2018) yang menyatakan bahwa umur reproduksi yang sehat dan aman adalah umur 20-30 tahun. Kehamilan di usia< 20 tahun dan diatas > 35 tahun dapat menyebabkan ibu mengalami Hiperemesis Gravidarum karena kehamilan di usia $<20$ tahun secara biologis belum optimal emosinya cenderung labil, mentalnya belum matang sehingga mudah mengalami guncangan yang mengakibatkan kurangnya perhatian terhadap pemenuhan kebutuhan zat-zat gizi selama kehamilan. 
Sedangkan pada usia> 35 tahun terkait dengan kemunduran dan penurunan daya tahan tubuh serta berbagai penyakit yang sering menimpa di usia ini

\section{Hasil Kejadian Hiperemesis Gravidarum Berdasarkan Umur Kehamilan Ibu}

Berdasarkan tabel di atas terlihat bahwa dari 75 ibu hamil di Bidan Praktek Mandiri ST.Nilawati S.ST sebanyak $6(8 \%)$ ibu hamil yang mengalami Hiperemesis Gravidarum pada umur kehamilan < 16 minggu, dan sebanyak 69 (92\%) ibu hamil yang mengalami Hiperemesis Gravidarum pada umur kehamilan $\geq 16$ minggu.

Hasil penelitian ini sesuai dengan teori Larasati (2018)yang menyatakan bahwa masa kehamilan dimulai dari konsepsi sampai lahirnya janin. Lamanya hamil normal atau Umur kehamilan adalah 280 hari (40 minggu atau 9 bulan 7 hari) dihitung dari hari pertama haid terakhir. Kehamilan dibagi dalam 3 triwulan yaitu triwulan pertama dimulai dari konsepsi sampai 3 bulan, triwulan kedua dari bulan keempat sampai 6 bulan, triwulan ketiga dari bulan ketujuh sampai 9 bulan.

Perasaan mual disebabkan meningkatnya kadar hormone estrogen dan HCG dalam serum. Pengaruh fisiologik kenaikan hormon ini belum jelas, mungkin karena sistem saraf pusat atau pengosongan lambung yang berkurang.Umumnya wanita dapat menyesuaikan dengan keadaan ini, meski gejala mual dan muntah berat dapat berlangsung sampai 4 bulan (16 minggu).

\section{Hasil Kejadian Hiperemesis Gravidarum Berdasarkan Gravida Ibu}

Berdasarkan tabel di atas terlihat bahwa dari $75 \mathrm{ibu}$ hamil dengan Hiperemesis Gravidarum Di Bidan Praktek Mandiri ST. Nilawati S.ST, terdapat 40 (53\%) ibu hamil yang mengalami Hiperemesis Gravidarum pada gravida hamil 2 dan 3. Dan terdapat 35 $(46,7 \%)$ ibu hamil yang mengalami Hiperemesis Gravidarum Pada gravida 1 dan $>3$.

Hasil penelitian ini sesuai dengan teori Larasati (2018) yang menyatakan bahwa gravida adalah seorang wanita yang hamil.Mual dan muntah terjadi pada $60 \%-80 \%$ wanita dengan kehamilan pertama (primigravida) dan 40-60\% pada wanita yang sudah pernah hamil (multigravida).

\section{Kesimpulan}

Berdasarkan hasil penelitian maka kesimpulan pada penelitian ini menunjukkan bahwa adi kesimpulannya terdapat 51 (68\%) kasus dengan kejadian hiperemesis gravidarum, yang berisiko tinggi berdasarkan umur ibu yaitu umur $<20->35$ tahun, lebih banyak terjadi pada gravida 1 dan $>3$, dan terjadi pada umur kehamilan < 16 minggu 


\section{Ucapan Terima Kasih}

Dalam kesempatan ini peneliti dengan tulus menyampaikan banyak terima kasih dan penghargaan setinggi-tingginya team peneliti atas kerjasama dalam selama proses meneliti, dan terkhusus kepada kedua orang tuaku yang tercinta orangtua serta kepada seluruh keluarga yang telah memberikan motivasi, doa dan pengorbanan materi maupun non-materi selama peneliti dalam proses pendidikan sampai selesai.

\section{Referensi}

Ali, S. (2018) Karakteristik Penderita Hiperemesis Gravidarum Yang Dirawat Inap di RSU Anutapura Palu Tahun 2018. Program Studi Pendidikan Dokter Fakultas Kedokteran Universitas Alkhairaat.

Andria. (2017). Pengetahuan Ibu Hamil Tentang hiperemesis Gravidarum di Rumah Sakit Umum Daerah Rokan Hulu. Prodi DIII Kebidanan Universitas Pasir Pengaraian .

Atika, I., Putra, H. K., \& Thaib, S. H. (2016). Hubungan Hiperemesis Gravidarum dengan Usia Ibu, Usia Gestasi, Paritas, dan Pekerjaan pada Pasien Rawat Inap di RSUP Dr. Moh. Hoesin Palembang. Jurnal Kedokteran dan Kesehatan: Publikasi Ilmiah Fakultas
Kedokteran Universitas Sriwijaya, 3(3), 166-171.

Cunningham FG, Gant NF, Leveno KL, Gilstrap III LC, Hauth JC, Wenstrom KD. (2006). Obstetrics William, Edisi ke-21. Jakarta: EGC, hlm. 181-213, 1424-5

Handayani, S., \& Aiman, U. (2018). Analisis Kejadian Hiperemesis Gravidarum (Heg) Berdasarkan Karakteristiknya. Babul Ilmi Jurnal Ilmiah Multi Science Kesehatan, 9(1).

Gunawan, K., Manengkei, P. S. K., \& Ocviyanti, D. (2011). Diagnosis dan Tata Laksana Hiperemesisi Gravidarum. $J$ Indon Med Assoc, Volum, 61.

Larasati, N., (2018). Gambaran Hiperemesis Gravidarum Di Rumah Sakit Umum Bogor Tahun 2018. Program studi diploma III kebidanan fakultas kedokteran dan ilmu kesehatan masyarakat Universitas Madya Bogor

Nurnaningsih, N. (2012). Gambaran FaktorFaktor Kejadian Hiperemesis Gravidarum pada Ibu Hamil Trimester Pertama di RSKDIA Siti Fatimah Makassar Tahun 2012 (Doctoral dissertation, Universitas Islam Negeri Alauddin Makassar).

Oktavia, L. (2016). Kejadian Hiperemisis Gravidarum Ditinjau dari Jarak 
Kehamilan dan Paritas. Jurnal Aisyah: Jurnal Ilmu Kesehatan, 1(2), Hal-41.

Rahma, T. R. S. M. (2016). Asuhan pada Ibu Hamil Trimester I dengan Hiperemesis Gravidarum Tingkat I. Jurnal Bidan, 2(2), 234047.

Rofi'ah, S., Widatiningsih, S., \& Arfiana, A. (2019). Studi Fenomenologi Kejadian Hiperemesis Gravidarum pada Ibu Hamil Trimester I. Jurnal Riset Kesehatan, 8(1), 41-52.

Saifuddin AB, Rachimhadi T, Winkjosastro GH. (2011). Ilmu Kebidanan, Sarwono Prawodihardjo. Edisi ke-4. Jakarta: PT Bina Pustaka Sarwono Prawodihardjo. Sumai, E., Keintjem, F., \& Manueke, I. (2014). Faktor-faktor yang berhubungan dengan kejadian Hiperemesis gravidarum di Rumah Sakit Umum Daerah dr. Sam Ratulangi Tondano Kabupaten Minahasa Provinsi Sulawesi Utara. JIDAN (Jurnal Ilmiah Bidan), 2(1), 61-65.

Wirakusumah, F. F., Martaadisoebrata, D., \& Effendi, J. S. (2019, December). Obstetri Patologi: Ilmu Kesehatan Reproduksi. EGC. 